\title{
Authority of Second-Tier Governments to Reduce Deforestation in 30 Tropical Countries
}

\author{
Jonah Busch* and Oyut Amarjargal \\ Earth Innovation Institute, San Francisco, CA, United States
}

The authority of state- and province-level governments ("second-tier governments") to make decisions related to slowing deforestation independently of national governments varies widely across countries. Here we systematically catalog whether second-tier governments in 30 tropical countries with high projected future emissions from deforestation possess 14 distinct types of general and forest-related authority. We compile this information in a free, open-access database. Second-tier governments have broadest authority to reduce deforestation in India, Brazil, Indonesia, Malaysia, Papua New Guinea, Peru, China, Laos, Mozambique, and Vietnam. Second-tier governments have the least authority in Central African Republic, Gabon, Angola, Madagascar, Bolivia, Cambodia, Cameroon, Guyana, Suriname, Thailand, and Venezuela. Second-tier

OPEN ACCESS

Edited by:

Amy E. Duchelle,

Center for International Forestry

Research (CIFOR), Indonesia

Reviewed by:

Ashwin Ravikumar,

Amherst College, United States

Kaisa Korhonen-Kurki,

University of Helsinki, Finland

*Correspondence:

Jonah Busch

jbusch@earthinnovation.org

Specialty section:

This article was submitted to

People and Forests,

a section of the journal

Frontiers in Forests and Global

Change

Received: 01 September 2019 Accepted: 02 January 2020

Published: 24 January 2020

Citation:

Busch J and Amarjargal O (2020) Authority of Second-Tier Governments to Reduce Deforestation in 30 Tropical

Countries.

Front. For. Glob. Change 3:1 doi: 10.3389/ffgc.2020.00001 governments have intermediate authority in Democratic Republic of Congo, Ecuador, Mexico, the Philippines, Colombia, Myanmar, Tanzania, Zambia, Mexico, and Republic of Congo. Authorities that second-tier governments most commonly possess include development planning, taxation, budgeting, and roads. Authorities that second-tier governments least commonly possess include land ownership, police, permits for mining, Indigenous affairs, and protected areas. Authorities possessed by an intermediate number of second-tier governments include spatial planning, elections, courts, and permits for agriculture. More than one-quarter of future emissions from deforestation between 2020 and 2050 is projected to come from just seven out of 678 second-tier jurisdictions: Amazonas, Pará, and Mato Grosso (Brazil), Équateur and Orientale (Democratic Republic of Congo), Loreto (Peru), and El Beni (Bolivia). After weighting for authority, our list of the 50 second-tier jurisdictions in the tropics that are the highest priority for reducing emissions from deforestation shifts to include fewer second-tier jurisdictions in Africa (where second-tier governments have 4.2 authorities out of 14 in the average country) and Latin America (6.3 authorities out of 14) and more second-tier jurisdictions in Asia (8.5 authorities out of 14). Second-tier jurisdictions that have formally expressed interest in reducing emissions from deforestation, e.g., through the Governors' Climate and Forest Task Force, Under2 Coalition, or New York Declaration on Forests, possess greater authority to reduce deforestation on average than other jurisdictions. Information on second-tier governmental authority, when complemented with deeper country-specific knowledge, can help initiatives for reducing emissions from deforestation (REDD+) prioritize support across regions and across sectoral interventions.

Keywords: REDD+, jurisdictional approach, multi-level governance, climate change, decentralization, subnational government 


\section{INTRODUCTION}

Reducing tropical deforestation is critical to preventing more than $2^{\circ} \mathrm{C}$ of global warming (IPCC, 2014). Furthermore, protecting forests prevents extinctions (IPBES, 2019) and contributes to sustainable development goals related to health, agriculture, energy, and climate adaptation (Seymour and Busch, 2016). Because the benefits of deforestation accrue to private land-use decision makers while the costs of deforestation are spread across a broad public, reducing deforestation to socially optimally levels requires interventions by governments.

There are multiple scales of government at which actions to reduce deforestation can take place-national, sub-national, and local. Domestically, national governments have the authority to enact and enforce a wide manner of public policies intended to slow deforestation, from protected areas to recognition of Indigenous territorial rights to payments for ecosystem services to road infrastructure to trade in agricultural products (Busch and Ferretti-Gallon, 2017). Internationally, national governments are the principals in international conventions related to reducing deforestation [e.g., United Nations Framework Convention on Climate Change (UNFCCC); Convention on Biological Diversity (CBD)]. They are the focal points for the provision of pledges to those conventions (e.g., Nationally Determined Contributions; National Biodiversity Strategy and Action Plans). They are the designated recipients of finance under the terms of the UNFCCC Paris Climate Agreement on Reducing Emissions from Deforestation and forest Degradation (REDD+). Meanwhile local governments are most closely adjacent to individual land-users who make decisions directly related to clearing, maintaining, or expanding forest cover (Boyd et al., 2018; Stickler et al., 2018).

In between the scale of national and local governments, sub-national governments have widely varying authority to independently make decisions related to slowing deforestation. Sub-national governments one administrative tier below the national government ("second-tier governments") are variously termed provinces, states, departments, regions, etc. Sub-national governments two administrative levels below the national government ("third-tier governments") are variously termed municipalities, districts, provinces, etc.

Although sub-national governments are unlikely to be able to comprehensively solve deforestation in isolation from national governments and local stakeholders, they can play an important role. International forums are increasingly paying attention to the potential for sub-national governments to contribute to reducing deforestation. The UNFCCC Warsaw Framework for REDD+ specifies that the scale for reference levels and monitoring may be sub-national as an interim measure if appropriate (UNFCCC, 2013). The New York Declaration on Forests has been signed by 21 sub-national governments (United Nations, 2014).

Finance for REDD+ has increasingly gravitated toward sub-national scales as well. Less-than-initially-anticipated levels of finance that are insufficient to incentivize actions by national governments have spurred the design of mechanisms to channel funds to sub-national governments, including the Forest Carbon Partnership Facility's Carbon Fund; Germany's
REDD Early Movers Program; the Governors' Climate and Forest Task Force; and the California Tropical Forest Standard. Meanwhile, proponents of REDD+ for voluntary markets have increasingly sought to bolster the environmental integrity of emission reductions by shifting scale from isolated projects to larger jurisdictions, e.g., the Verra Jurisdictional and Nested REDD+ Framework.

Previous studies have explored a wide range of topics related to the potential for sub-national governments to contribute to reducing deforestation. Multi-level governance of REDD+ has been explored by Forsyth (2009), Korhonen-Kurki et al. (2013), Ravikumar et al. (2015), Larson et al. (2018), and di Gregorio et al. (2019). REDD+ and the recentralization of forest governance has been analyzed by Phelps et al. (2010). The relative effectiveness of different scales of government to reduce deforestation through protected areas has been evaluated in Brazil by Herrera et al. (2019). Mechanisms for the effective, efficient and equitable distribution of REDD+ revenues between national and state governments have been designed, e.g., in Brazil (Cattaneo, 2011) and Indonesia (e.g., Busch et al., 2012). Ecological fiscal transfers, which tie the devolution of funding from national to state governments to forest cover, have been evaluated in India (Busch and Mukherjee, 2017) and proposed for Indonesia (Mumbunan, 2018). Sub-national REDD+ programs have been designed, e.g., in Indonesia (Irawan et al., 2019). And a "jurisdictional approach" to low-emission rural development has been put forward, based around public-private collaboration in sub-national jurisdictions (Nepstad et al., 2013a,b; Stickler et al., 2018).

Yet until now, there has been no systematic compilation of which authorities to reduce deforestation are possessed by sub-national governments in which countries. In this paper we construct a database in which we systematically catalog which types of authority to reduce deforestation are possessed by second-tier governments in which countries. We catalog authorities for states and provinces in 30 tropical countries projected to produce $91 \%$ of emissions from tropical deforestation from 2020 to 2050 (Busch et al., 2019). For each country we catalog whether or not second-tier governments in that country possess five measures of general authority and nine measures of forest-related authority. No such data set existed previously.

We use this database to answer two questions. First, in which countries do second-tier governments have the greatest authority to reduce deforestation? By identifying sub-national jurisdictions that have high de jure governmental authority to reduce deforestation, our analysis adds to the suite of information that institutions concerned with jurisdictionalscale initiatives for reducing deforestation can use to prioritize resources across regions. Second, which types of authority to reduce deforestation do second-tier governments most broadly possess? By identifying authorities that are broadly possessed by second-tier governments in many countries, our analysis can help institutions prioritize resources across sectoral interventions.

We present an illustrative example of how data on crossnational variation in second-tier government authority can be used to inform prioritization. We compare the most significant 
second-tier jurisdictions for reducing emissions from tropical deforestation based on (i) projected future emissions alone, and (ii) projected future emissions weighted by second-tier government authority.

\section{MATERIALS AND METHODS}

\section{Selection of Countries and Jurisdictions}

We selected for inclusion in the study the 30 countries with the highest projected emissions from tropical deforestation from 2020 to 2050 under a business-as-usual scenario (Busch et al., 2019). These countries are collectively projected to produce $91 \%$ of emissions. Of these 30 countries, 9 are in Latin America; 10 are in Sub-Saharan Africa; and 11 are in tropical Asia.

Within these countries, we looked at the authority of secondtier governments only. Among the 30 countries studied, secondtier governments are variously termed provinces $(n=14 / 30)$, regions $(n=7 / 30)$, states $(n=6 / 30)$, departments $(n=3 / 30)$, or other terms; the median country has 23 of these (Table 1). Third-tier governments are variously termed municipalities $(n=$ $12 / 30)$, districts $(n=10 / 30)$, provinces $(n=2 / 30)$, or other terms; the median country has 166 of these. The authority of thirdtier governments is also significant in some countries, and may even exceed that of second-tier governments for some indicators in some countries. However, we did not extend the scope of the present analysis to third-tier governments as information on these governments is harder to come by for many countries. The authority of third-tier governments would be an interesting topic for future exploration.

\section{Selection of Indicators of Authority}

We selected 14 indicators of second-tier government authority to compare across countries. These included five indicators of general authority and nine indicators of forest-related authority.

The five indicators of general authority are intended to measure whether second-tier governments have at least some electoral, fiscal, and judicial independence from higher levels of government, and thus can act at least somewhat autonomously rather than being entirely beholden to or dependent on the national government to take actions. We produced binary indicators of whether second-tier governments do or do not have that authority.

The five indicators of general second-tier government authority are as follows:

1. Elections. Whether electoral accountability on its own slows or accelerates environmental degradaton is theoretically ambiguous (Li and Reuveny, 2006). But governments that are elected by their citizens will have greater autonomy to reduce deforestation, if they so choose, than those dependent on higher levels of government for their appointment. We coded this indicator as 1 if at least some second-tier government officials, i.e., governors and legislators, are elected by voters within that jurisdiction rather than, e.g., appointed by a president, prime minister, or parliament. We coded this indicator as 0 otherwise.
TABLE 1 | Numbers and names of sub-national jurisdictions in 30 tropical countries with greatest projected emissions from deforestation.

\begin{tabular}{|c|c|c|}
\hline Country & $\begin{array}{l}\text { Number and name of } \\
\text { second-tier jurisdictions }\end{array}$ & $\begin{array}{l}\text { Number and name of } \\
\text { third-tier jurisdictions }\end{array}$ \\
\hline Brazil & 26 States, 1 Federal District & 5,570 Municipalities \\
\hline Indonesia & 34 Provinces & 410 Districts, 98 Cities \\
\hline Dem. Rep. Congo & 26 Provinces & 145 Territories, 33 Cities \\
\hline Bolivia & 9 Departments & 94 Provinces \\
\hline Colombia & $\begin{array}{l}32 \text { Departments, } 1 \text { Capital } \\
\text { District }\end{array}$ & 1,101 Municipalities \\
\hline Peru & 25 Regions & 196 provinces \\
\hline $\begin{array}{l}\text { Papua New } \\
\text { Guinea }\end{array}$ & $\begin{array}{l}20 \text { Provinces, } 1 \\
\text { Autonomous region, } 1 \\
\text { District }\end{array}$ & 89 Districts \\
\hline Venezuela & $\begin{array}{l}23 \text { States, } 1 \text { Capital District, } \\
1 \text { Federal Dependency }\end{array}$ & 336 Municipalities \\
\hline Malaysia & 13 States & 149 Municipalities \\
\hline Zambia & 10 Provinces & 74 Districts \\
\hline Republic of Congo & 12 Departments & 94 Municipalities \\
\hline Angola & 18 Provinces & 162 Municipalities \\
\hline Mexico & 32 States, 1 Federal District & 2,457 Municipalities \\
\hline Myanmar & $\begin{array}{l}7 \text { Regions, } 7 \text { States, } 1 \\
\text { Union Territory }\end{array}$ & 74 Districts \\
\hline $\begin{array}{l}\text { Central African } \\
\text { Republic }\end{array}$ & 16 Prefectures & 66 Sub-prefectures \\
\hline Vietnam & $\begin{array}{l}58 \text { Provinces, } 5 \\
\text { Municipalities }\end{array}$ & 710 Districts \\
\hline Thailand & 76 Provinces & 209 Municipalities \\
\hline Cameroon & 10 Regions & 58 Departments \\
\hline Philippines & 81 Provinces & $\begin{array}{l}\text { 1,489 Municipalities, } 105 \\
\text { Cities }\end{array}$ \\
\hline India & 29 States, 7 Union territories & $\begin{array}{l}250,671 \text { Municipalities, } 630 \\
\text { Zilla panchayats, } 6,614 \\
\text { Block panchayats, } 253,163 \\
\text { Gram panchayats }\end{array}$ \\
\hline Cambodia & 24 Provinces, 1 Municipality & $\begin{array}{l}159 \text { Districts, } 26 \\
\text { Municipalities, } 12 \text { Khans }\end{array}$ \\
\hline Tanzania & 31 Regions & 169 Districts \\
\hline Laos & 17 Provinces, 1 prefecture & 141 Districts \\
\hline Mozambique & 11 Provinces & 154 Districts \\
\hline Guyana & 10 Regions & $\begin{array}{l}6 \text { Municipal, } 65 \\
\text { Neighborhood democratic } \\
\text { councils, } 75 \text { Amerindian } \\
\text { village councils }\end{array}$ \\
\hline China & 31 Provinces & 334 Prefectures \\
\hline Gabon & 9 Provinces & 47 Departments/prefectures \\
\hline Ecuador & 24 Provinces & 221 Municipalities \\
\hline Madagascar & 22 Regions & 111 Districts \\
\hline Suriname & 10 Districts & 62 Sub-districts \\
\hline
\end{tabular}

2. Taxation. Governments that can raise their own revenue and are at least partially self-financing will have greater autonomy than those dependent on higher levels of government for their fiscal balance. In principle taxation powers can also be used to correct negative environmental externalities such as those arising from deforestation, though this type of taxation is rare in practice (e.g., Müller et al., 2013). We coded this indicator as 1 if the second-tier government has the authority to raise at least some types of taxes, and 0 otherwise. 
3. Budgets. Governments that can determine their own $\overline{\text { spending }}$ will have greater autonomy than those whose budgets are determined by higher levels of government. Public budgets can be used to finance a wide range of policies or programs to reduce deforestation (e.g., payments for ecosystem services; Wunder, 2005) or accelerate it (e.g., subsidies for agricultural expansion; Mamun et al., 2017). We coded this indicator as 1 if the second-tier government has at least some authority to determine its own budget. This includes countries where second-tier government authority to set budgets is partially constrained by national governments or participatory processes. We coded this indicator as 0 otherwise.

4. Police. Enforcement of environmental laws is consistently associated with lower deforestation (Busch and FerrettiGallon, 2017). Governments that operate their own police forces will have greater autonomy to enforce laws and policies than those in which police in their jurisdiction report to the national government. We coded this indicator as 1 if the second-tier government maintains their own police force, and 0 otherwise. We did not consider other administrative agencies of second-tier governments that are not police departments but nevertheless might possess some police-like authorities (e.g., to make arrests or use force).

5. Courts. As with police, enforcement of environmental laws by courts can reduce deforestation (Busch and Ferretti-Gallon, 2017). Governments that have their own courts will have greater autonomy to enforce laws and policies than those in which justice is administered solely under the national judicial system. We coded this indicator as 1 if the second-tier government has its own court system, and 0 otherwise.

The nine indicators of forest-related authority are intended to measure the degree to which second-tier governments independently oversee processes that can affect the rate of deforestation, e.g., as identified by Busch and Ferretti-Gallon (2017) and related reviews (Angelsen and Kaimowitz, 1999; Geist and Lambin, 2002; Chomitz, 2007; Rudel et al., 2009; Angelsen and Rudel, 2013; Pfaff et al., 2013; Burivalova et al., 2019). We sought double-binary indicators, that is, indicators for which (1) the authority involves a yes/no decision on the part of the second-tier government; and (2) it would be easy to clearly identify whether governments do or do not have the authority.

The nine indicators of second-tier governments' forest-related authority are as follows:

6. Land ownership. Governments that own land have direct responsibility for forest management, including some control over the rate of deforestation and degradation on that land. We coded this indicator as 1 if the secondtier government owns at least some land or forest, and 0 otherwise. We did not consider the provenance of secondtier government-owned land; e.g., whether it was obtained through the dispossession of local groups.

7. Agricultural permits. Agriculture is the leading driver of deforestation across much of the tropics (Curtis et al., 2018). Control over the issuing of licenses for agriculture in forest areas is a direct way that governments can accelerate or curtail deforestation. We coded this indicator as 1 if second-tier governments have at least some authority to issue licenses or concessions for agricultural activity, and 0 otherwise.

8. Mining permits. Mining is a significant driver of deforestation in some tropical regions (e.g., Butsic et al., 2015). As with agriculture, control over the issuing of licenses to mine in forest areas is a direct way that governments can accelerate or curtail deforestation. We coded this indicator as 1 if the second-tier governments have at least some authority for issue licenses or concessions for mining, and 0 otherwise.

9. Logging permits. Logging and timber operations have a mixed effect on deforestation across the tropics (Busch and Ferretti-Gallon, 2017). In some regions the roads and forest degradation associated with logging are precursors to more widespread deforestation afterward (e.g., Rice et al., 1997). Elsewhere, logging companies have rights and incentives to manage forests for long-term production rather than short-term liquidation (e.g., Putz and Romero, 2015). In either case government oversight of logging can lead to more environmentally sustainable operations. We coded this indicator as 1 if second-tier governments have at least some authority for issuing licenses or concessions for logging, and 0 otherwise.

10. Roads. The construction of roads is an important driver of deforestation throughout the tropics, both directly by increasing access to previously remote forest areas (Barber et al., 2014) and indirectly by reducing the cost of transporting agricultural products to urban markets (Cropper et al., 2001). Building or prohibiting roads is a direct way that governments can accelerate or curtail deforestation. We coded this indicator as 1 if secondtier governments have authority for the construction and maintenance of at least some roads, and 0 otherwise.

11. Protected areas. Protected areas, whether strict or multiple-use, are consistently associated with lower rates of deforestation across the tropics (Busch and Ferretti-Gallon, 2017). Designating protected areas in threatened forests is a direct way that governments can curtail deforestation. We coded this indicator as 1 if second-tier governments have authority to designate areas within its territory as protected, and 0 otherwise.

12. Indigenous affairs. Forests in which Indigenous peoples' territorial claims have been recognized are consistently associated with lower rates of deforestation (Busch and Ferretti-Gallon, 2017). Recognizing and protecting the territorial rights of indigenous peoples and other traditional communities is a direct way for governments to curtail deforestation. We coded this indicator as 1 if secondtier governments have authority to recognize indigenous territories or affairs, and 0 otherwise.

13. Spatial planning. Zoning of where specified economic activities can take, even if non-binding, has the potential to accelerate or curtail deforestation (e.g., Vasconcelos et al., 2013). We coded this indicator as 1 if second-tier 
governments have at least some responsibility for territorial planning, and 0 otherwise.

14. Development planning. Planning which economic activities will be encouraged or discouraged within a jurisdiction can affect deforestation (e.g., Pedlowski et al., 1997). We coded this indicator as 1 if second-tier governments have at least responsibility for development planning, and 0 otherwise.

We coded a country-authority combination as 1 if second-tier governments in that country possessed that authority. We did so even in cases in which that authority was not exclusive, i.e., even when second-tier governments shared the authority with another level of government. We coded a country-authority combination as 0 if second-tier governments do not possess that authority, i.e., it rested entirely with another level of government. We coded partial authority as 1; e.g., when some second-tier governments in a country have the authority while other second-tier governments in the same country don't; when the authority is being phased out or being phased in; or when second-tier governments only possess that authority for certain aspects of the indicator (e.g., second-tier governments have the authority to grant mining permits for organic materials but not minerals; or to set valueadded taxes but not income taxes). By deliberately coding partial or underused authorities as 1, we erred on the side of inclusivity. In this way we avoided errors of omission (i.e., not ascribing authorities that exist) even while remaining prone to errors of commission (i.e., ascribing authorities that are not fully devolved or used).

This list of indicators is not a comprehensive overview of all authorities that second-tier governments possess that could affect deforestation. We did not compile information on, e.g., secondtier governments' authority to oversee forest monitoring systems or social and environmental safeguard information systems, nor extent of enforcement of regulations. Nor did we attempt to assess second-tier governments' capacity or political will to undertake processes that they have authority for.

\section{Data}

Some sources of information were particularly useful. For example, the Constitute Project (2019) hosts up-to-date versions of all countries' constitutions, many of which are explicit about which general and forest-related authorities rest with which level of government. Landlinks (USAID, 2019), an initiative of USAID related to land tenure and property rights, maintains country profiles with useful information related to many forest-related indicators. The World Database on Protected Areas (UNEP-WCMC, 2014), which maintains a nearly comprehensive and current map of protected areas worldwide and their management agency, was our primary resource for the indicator on second-tier governments' authority to declare protected areas. The World Factbook (CIA, 2019) provides information on many countries' court systems, as well as on the number of second-tier jurisdictions. The African Policing Civilian Oversight Forum (APCOF, 2019) provides information related to second-tier governments' police authority for many African countries. OECD country profiles provided information related to planning and land ownership for some countries.
World Resources Institute's Forest Legality Initiative (WRI, 2019) provided information related to land ownership and logging permits for some countries.

Furthermore, some previous publications provided useful information related to second-tier governments' authorities for individual countries. A publication series commissioned by the Center for International Forestry provided useful information for Indonesia (Ardiansyah et al., 2015), Mexico (Carrillo Fuentes and Velasco Ramirez, 2016), Peru (Wieland and Farfan, 2015), Tanzania (Mbwambo, 2015), and Vietnam (Trung et al., 2015). The 12 sources mentioned above provided information on 243 out of 420 (58\%) of country-authority combinations; we obtained information on the remaining $42 \%$ country-authority combinations from other sources.

In attempting to code country-authority combinations accurately we faced several persistent challenges. Data were obtained from multiple heterogeneous sources, making standardization difficult. In some cases, available information was ambiguous as to the possession of authority. In some cases, available information may not have been current, raising the possibility that the information might be outdated and might have been superseded. In some countries there could be important differences between authorities as described on paper (de jure authorities) and authorities as they exist in practice (de facto authorities). This difference could occur at all times, or in times of war or civil unrest. We coded based on de jure authority. In some cases, multiple sources conflicted in their description of which levels of government hold certain authority. Semantically, source texts did not always clearly differentiate between "states" (i.e., second-tier governments) and "the state" (i.e., the national government). These challenges meant that some judgment calls and margin for error were inherent in the coding process. Representative examples for the coding of each indicator are shown in Box 1.

We compiled information on all 30 countries and 14 authorities in a database. The database contains both elaborated data (with the full relevant information quoted along with its source) and simplified data (1 or 0 only). The database is freely available online as Supplementary Table 1.

\section{Aggregation}

For each country, we produced a second-tier government authority score out of a maximum of 14 by summing the binary scores for all 14 indicators. In our method of aggregation, all 14 authorities contributed equally to the second-tier government authority score. In reality, some authorities contribute more strongly than others to a second-tier government's ability to reduce deforestation. For example, spatial planning is generally a non-binding exercise rather than a strong legal tool, while roads permanently and substantially alter the geographic benefits and costs of converting forest cover to agriculture or other land uses. Nevertheless, in the absence of a quantitative basis for weighting authorities heterogeneously, we weighted all 14 authorities equally.

For each authority, we produced a score out of a maximum of 30 by summing the scores across all 30 countries. 
BOX 1 | Representative examples for each indicator.

Elections: Do states in Brazil have independent elections? "Each of Brazil's 26 states has its own constitution and popularly elected legislature and governor" (Nations Encyclopedia, 2019). Coded as 1 (yes).

Taxation: Do provinces in the Democratic Republic of Congo have taxation authority? "Without prejudice to the other provisions of this Constitution, the following matters are of the exclusive competence of the Provinces: provincial and local taxes, and duties and assessments [droits], notably property tax, tax on local revenue and the tax on motor vehicles" (Constitute Project, 2019). Coded as 1 (yes).

Budgets: Do states in Venezuela have budget authority? "The Legislative Power is exercised in each State by a Legislative Council...The Legislative Council has the following attributions:... To approve the Law of the Budget of the State" (Constitute Project, 2019). Coded as 1 (yes).

Police: Do departments in Bolivia have police authority? "Police [are] subordinate to the [National] Ministry of Interior, Migration, and Justice" (Hudson et al., 1991). Coded as 0 (no).

Courts: Do provinces in Papua New Guinea maintain courts? "Subordinate courts [include] district, village, and juvenile courts, military courts, taxation courts, coronial courts, mining warden courts, land courts, traffic courts, committal courts, grade five courts" (CIA, 2019). Coded as 0 (no).

Land ownership: Do states in Mexico own land? "According to the constitution, all land and water in Mexico belongs to the nation and the national government is in charge of providing legislation to operationalise this principle" (OECD, 2016). Coded as 0 (no).

Agricultural permits: Do regions and states in Myanmar have authority to issue agricultural permits? "With the enactment of the Farmland Law, those seeking rights to farmland must obtain permission and a land-use certificate (LUC) from the [national] state (USAID, 2019)" (WRI, 2019). Coded as 0 (no).

Mining permits: Do departments in Colombia have authority to issue mining permits? "All non-renewable natural resources in Colombia belong to the state, which can undertake exploration and exploitation on its own or grant concession rights to private parties to undertake exploration and exploitation" (USAID, 2019). Coded as 0 (no).

Logging Permits: Do regions in Peru have authority to grant logging concessions? "The [National] Forestry and Wildlife Agency has the power to grant forest concessions over all regions, except for the powers transferred to the regional governments... Regional governments grant forest concessions in areas inside the regions where functions have been transferred" (Fernandini and Sousa, 2015). Coded as 1 (yes)

Roads: Do provinces in the Philippines have authority to build roads? "Infrastructure facilities intended to service the needs of the residents of the province and which are funded out of provincial funds includ[e], but [are] not limited to, provincial roads and bridges..." (Chan Robles Virtual Law Library, 2019$)$. Coded as 1 (yes). Protected areas: Do regions in Tanzania have authority to declare protected areas? "[National] authority to establish and gazette protected areas" (Mbwambo, 2015). Coded as 0 (no).

Indigenous affairs: Do provinces in Angola have authority to recognize Indigenous territories or affairs? "The state shall recognize the status, role and functions of the institutions of the traditional authorities founded in accordance with customary law which do not contradict the Constitution" (Constitute Project, 2019). Coded as 0 (no).

Spatial planning: Do provinces in Zambia conduct spatial planning? "Concurrent national and provincial functions: Nature conservation, provincial spatial planning and development, public transport, agriculture" (Constitute Project, 2019). Coded as 1 (yes).

Development planning: Do provinces in Indonesia conduct development planning? "[Provincial governments have] lawmaking authority in a number of fields of governance. These fields are development planning and control; spatial planning, use and monitoring; peace and order; public facilities and infrastructures" (Ardiansyah et al., 2015). Coded as 1 (yes).

\section{Caveats}

There are several notable caveats to our analysis. We developed binary scores in order to facilitate quantitative cross-national and cross-sectoral comparisons. But simple binary scores belie oftencomplex realities. Our database includes more nuanced and elaborate descriptions of every country-authority combination, on which the binary scores are based. For actual institutional decision-making, our assessments of the extent to which particular second-tier governments possess specific authorities should be followed up with deeper country-specific information gathering, e.g., through country-specific case studies.

We have identified second-tier jurisdictions in which governments have greater authority to reduce deforestation relative to their peers. While this data may be useful to institutions supporting state- and province-level initiatives for reducing emissions from deforestation to consider as they prioritize support across regions, it is by no means the only important information to consider. Other considerations include the values of local constituents and decision-makers, and regional history and politics surrounding land use (e.g., Myers et al., 2018).

There can be differences between de jure possession of authority and de facto exercise of those authorities. The degree to which second-tier governments exercise their authorities to reduce deforestation in practice can be hampered by, e.g., lack of capacity (DeFries et al., 2013), weak governance (KorhonenKurki et al., 2014), corruption (Sundstrom, 2016), or lack of political will to take on entrenched interests or illegal activities (Seymour and Busch, 2016).

While second-tier governments can play an important role in curtailing deforestation, they are not the only important stakeholders. In most if not all cases national governments possess more authority than second-tier governments. In some cases third-tier governments or local governments possess more authority than secondtier governments. In many places, Indigenous peoples and local communities, private companies, and nongovernmental organizations are relevant stakeholders as well.

Many of the above considerations are beyond the scope of this paper and suggest avenues for complementary research.

\section{RESULTS}

\section{Second-Tier Governments With Most Authority}

The authority of sub-national governments to reduce deforestation varies widely across countries (Figure 1 and 
Table 2). The countries in which second-tier governments have greatest authority, i.e., are in the top third, include India (with 14 out of 14 authorities); Brazil, Indonesia, and Malaysia (each with 12/14); Papua New Guinea and Peru (10/14); and China, Laos, Mozambique, and Vietnam (8/14). These are countries with substantial devolution of authority to second-tier governments.

The countries in which second-tier governments have the least authority, i.e., are in the bottom third, are Central African Republic and Gabon (each with 1 out of 14 authorities); Angola and Madagascar (2/14); Bolivia (3/14); Cambodia, Cameroon, Guyana, Suriname, Thailand, and Venezuela (4/14). These are countries with strong central control.

In between are Democratic Republic of Congo, Ecuador, Mexico, and the Philippines (7/14); Colombia, Myanmar, Tanzania, and Zambia (6/14); and Republic of Congo (5/14). These are countries where authorities are more balanced between national and second-tier governments.

On average, second-tier governments in the 11 countries within Asia have the most authority
(8.5/14). Second-tier governments in the 10 countries within Africa have the least authority $(4.2 / 14)$. And second-tier governments in the 9 countries within Latin America have intermediate authority (6.3/14).

Projections of future unweighted emissions from tropical deforestation are distributed unevenly across secondtier jurisdictions (Table 3). More than one-quarter of future emissions from tropical deforestation between 2020 and 2050 are projected to come from just seven of 678 second-tier jurisdictions: the states of Amazonas, Pará, and Mato Grosso in Brazil, the provinces of Équateur and Orientale in Democratic Republic of Congo, the region of Loreto in Peru, and the department of El Beni in Bolivia.

On average, pairs of countries had the same score on 8.6 out of 14 indicators (Figure 2; standard deviation $=2.5$ ). The greatest commonality between any pair of countries was between Gabon and the Central Africa Republic with the same score for all 14 indicators, as well as between Cameroon,

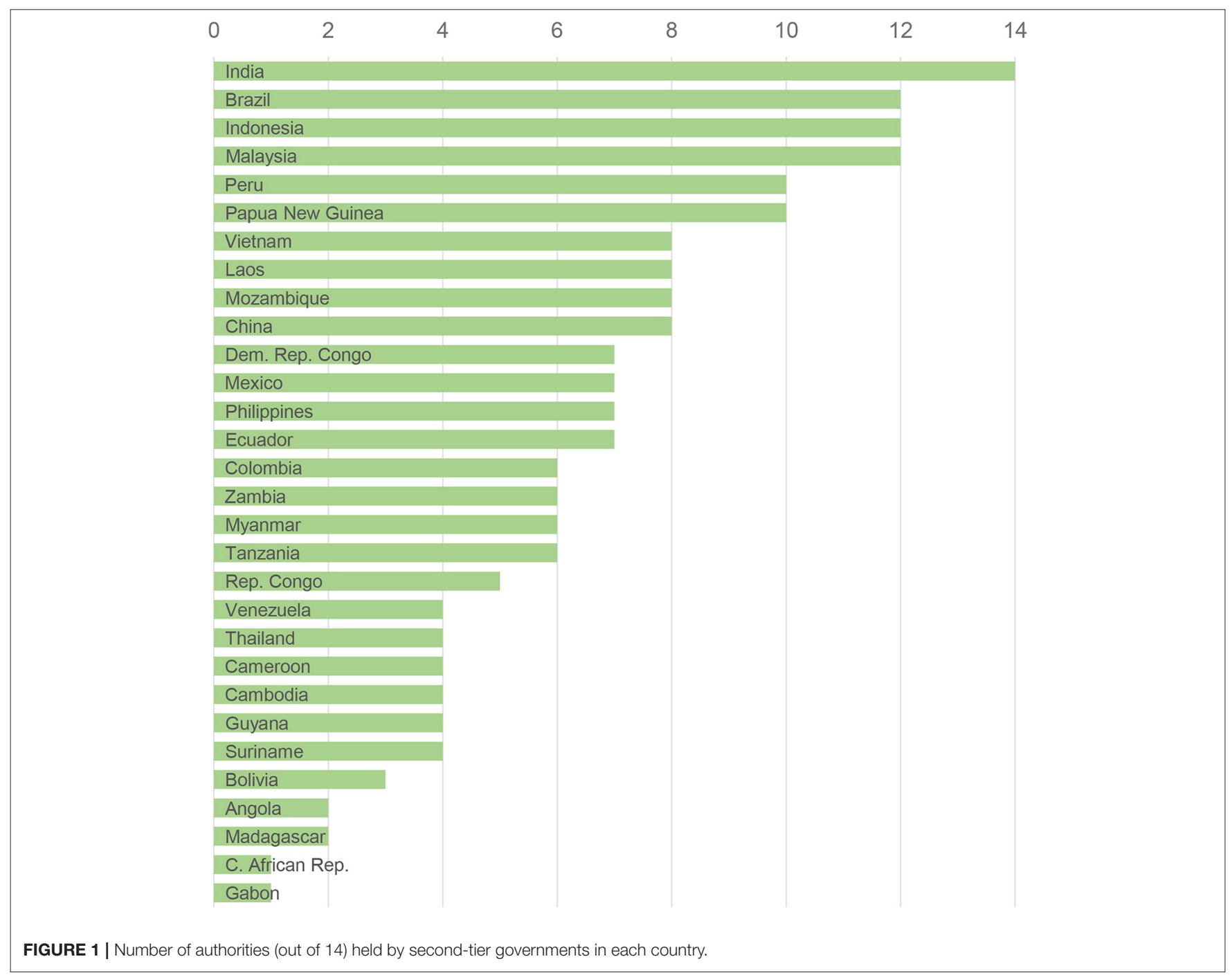


TABLE 2 | Authorities of second-tier governments, by country.

Total Elections Taxation Budgets Police Courts Land Agricultural Mining Logging Roads Protected Indigenous Spatial Development (/14) ownership Permits Permits permits

areas affairs planning planning

\begin{tabular}{|c|c|c|c|c|c|c|c|c|c|c|c|c|c|c|c|}
\hline TOTAL (/30) & & 15 & 25 & 23 & 4 & 13 & 3 & 12 & 6 & 11 & 21 & 8 & 8 & 16 & 27 \\
\hline Brazil & 12 & 1 & 1 & 1 & 1 & 1 & 1 & 1 & 0 & 1 & 1 & 1 & 0 & 1 & 1 \\
\hline Indonesia & 12 & 1 & 1 & 1 & 0 & 1 & 0 & 1 & 1 & 1 & 1 & 1 & 1 & 1 & 1 \\
\hline D.R. Congo & 7 & 1 & 1 & 1 & 0 & 0 & 0 & 1 & 0 & 0 & 1 & 0 & 1 & 0 & 1 \\
\hline Bolivia & 3 & 0 & 0 & 0 & 0 & 1 & 0 & 0 & 0 & 0 & 1 & 0 & 0 & 0 & 1 \\
\hline Colombia & 6 & 1 & 1 & 1 & 0 & 0 & 0 & 0 & 0 & 0 & 1 & 0 & 0 & 1 & 1 \\
\hline Peru & 10 & 1 & 1 & 1 & 0 & 0 & 0 & 1 & 1 & 1 & 1 & 0 & 1 & 1 & 1 \\
\hline PNG & 10 & 1 & 1 & 1 & 0 & 0 & 0 & 1 & 0 & 1 & 1 & 1 & 1 & 1 & 1 \\
\hline Venezuela & 4 & 1 & 1 & 1 & 0 & 0 & 0 & 0 & 1 & 0 & 0 & 0 & 0 & 0 & 0 \\
\hline Malaysia & 12 & 1 & 1 & 1 & 0 & 0 & 1 & 1 & 1 & 1 & 1 & 1 & 1 & 1 & 1 \\
\hline Zambia & 6 & 0 & 1 & 1 & 0 & 0 & 0 & 1 & 0 & 0 & 1 & 0 & 0 & 1 & 1 \\
\hline R. Congo & 5 & 0 & 0 & 1 & 0 & 0 & 0 & 1 & 0 & 0 & 1 & 0 & 0 & 1 & 1 \\
\hline Angola & 2 & 0 & 0 & 0 & 0 & 1 & 0 & 0 & 0 & 0 & 0 & 0 & 0 & 0 & 1 \\
\hline Mexico & 7 & 1 & 1 & 0 & 1 & 1 & 0 & 0 & 0 & 0 & 0 & 1 & 0 & 1 & 1 \\
\hline Myanmar & 6 & 0 & 1 & 1 & 1 & 1 & 0 & 0 & 0 & 0 & 1 & 0 & 0 & 0 & 1 \\
\hline C. Afr. Rep. & 1 & 0 & 1 & 0 & 0 & 0 & 0 & 0 & 0 & 0 & 0 & 0 & 0 & 0 & 0 \\
\hline Vietnam & 8 & 0 & 1 & 1 & 0 & 1 & 0 & 0 & 0 & 1 & 1 & 1 & 0 & 1 & 1 \\
\hline Thailand & 4 & 0 & 1 & 1 & 0 & 0 & 0 & 0 & 0 & 0 & 1 & 0 & 0 & 0 & 1 \\
\hline Cameroon & 4 & 0 & 1 & 1 & 0 & 0 & 0 & 0 & 0 & 0 & 1 & 0 & 0 & 0 & 1 \\
\hline Philippines & 7 & 1 & 1 & 1 & 0 & 0 & 0 & 0 & 0 & 0 & 1 & 1 & 0 & 1 & 1 \\
\hline India & 14 & 1 & 1 & 1 & 1 & 1 & 1 & 1 & 1 & 1 & 1 & 1 & 1 & 1 & 1 \\
\hline Cambodia & 4 & 0 & 1 & 1 & 0 & 1 & 0 & 0 & 0 & 0 & 0 & 0 & 0 & 0 & 1 \\
\hline Tanzania & 6 & 1 & 1 & 1 & 0 & 0 & 0 & 0 & 0 & 1 & 0 & 0 & 0 & 1 & 1 \\
\hline Laos & 8 & 0 & 1 & 1 & 0 & 1 & 0 & 1 & 0 & 1 & 1 & 0 & 1 & 0 & 1 \\
\hline Mozambique & 8 & 0 & 1 & 1 & 0 & 1 & 0 & 1 & 0 & 1 & 1 & 0 & 0 & 1 & 1 \\
\hline Guyana & 4 & 1 & 1 & 1 & 0 & 0 & 0 & 0 & 0 & 0 & 0 & 0 & 0 & 0 & 1 \\
\hline China & 8 & 0 & 0 & 0 & 0 & 1 & 0 & 1 & 1 & 1 & 1 & 0 & 1 & 1 & 1 \\
\hline Gabon & 1 & 0 & 1 & 0 & 0 & 0 & 0 & 0 & 0 & 0 & 0 & 0 & 0 & 0 & 0 \\
\hline Ecuador & 7 & 1 & 1 & 1 & 0 & 1 & 0 & 0 & 0 & 0 & 1 & 0 & 0 & 1 & 1 \\
\hline Madagascar & 2 & 1 & 0 & 0 & 0 & 0 & 0 & 0 & 0 & 0 & 0 & 0 & 0 & 0 & 1 \\
\hline Suriname & 4 & 0 & 1 & 1 & 0 & 0 & 0 & 0 & 0 & 0 & 1 & 0 & 0 & 0 & 1 \\
\hline
\end{tabular}

Suriname, and Thailand, also with the same score for all 14 indicators. The least commonality was between Central African Republic and India, with the same score on only 1 indicator.

Pairs of countries within the same continent were slightly more likely to have the same score than countries on different continents, sharing a score on 9.0 out of 14 indicators on average. Pairs of countries within Africa shared a score on 9.6 indicators on average; pairs of countries within Latin America shared a score on 8.8 authorities on average; and pairs of countries within Asia shared a score on 8.6 indicators on average.

Second-tier jurisdictions that are participating in prominent international climate and forest initiatives have greater authority on average than other second-tier jurisdictions. Within the 30 countries studied, the 32 second-tier jurisdictions in the Governors' Climate and Forest Task Force have an average authority score of 10.3; the 49 second-tier jurisdictions in the Under2 Coalition have an average authority score of 9.1; and the 17 signatories to the New York Declaration on Forests have an average authority score of 9.8. The authority scores for these jurisdictions greatly exceed the average authority score across the 30 countries studied (6.4) and the average authority score of the 759 second-tier jurisdictions within those 30 countries (7.0).

\section{Authorities Possessed by the Most Second-Tier Governments}

The types of general authority that second-tier governments have in the most countries, i.e., are in the top third, include taxation (possessed by 25/30 countries) and budgeting (23/30) (Figure 3 and Table 2). This suggests second-tier governments can consider funding programs as a way to reduce deforestation. In principle tax policy could also be used to discourage deforestation, although in many countries second-tier governments 
TABLE 3 | Top 50 second-tier jurisdictions by projected emissions from deforestation, unweighted vs. weighted by authority.

\begin{tabular}{|c|c|c|c|c|}
\hline & Top 50 states, unweighted & $\begin{array}{l}\text { Cumulative projected } \\
\text { emissions, unweighted \% }\end{array}$ & Top 50 states, weighted & $\begin{array}{l}\text { Cumulative projected } \\
\text { emissions, weighted } \%\end{array}$ \\
\hline 1 & Amazonas (Brazil) & 8 & Amazonas (Brazil) & 11 \\
\hline 3 & Mato Grosso (Brazil) & 17 & Mato Grosso (Brazil) & 24 \\
\hline 4 & Équateur (DRC) & 20 & Loreto (Peru) & 27 \\
\hline 7 & El Beni (Bolivia) & 26 & Équateur (DRC) & 33 \\
\hline 8 & Santa Cruz (Bolivia) & 28 & Kalimantan Barat (Indonesia) & 35 \\
\hline 9 & Riau (Indonesia) & 30 & Papua (Indonesia) & 37 \\
\hline 10 & Katanga (DRC) & 32 & Orientale (DRC) & 39 \\
\hline 11 & Kalimantan Tengah (Indonesia) & 33 & Sumatera Selatan (Indonesia) & 41 \\
\hline 16 & Minas Gerais (Brazil) & 39 & Maranhão (Brazil) & 48 \\
\hline 17 & Bandundu (DRC) & 40 & Katanga (DRC) & 49 \\
\hline 18 & Roraima (Brazil) & 41 & Bahia (Brazil) & 50 \\
\hline 19 & Sarawak (Malaysia) & 42 & Western (PNG) & 51 \\
\hline 20 & Western (PNG) & 43 & Rondônia (Brazil) & 52 \\
\hline 21 & Maranhão (Brazil) & 44 & Mato Grosso do Sul (Brazil) & 53 \\
\hline 22 & Bahia (Brazil) & 45 & Tocantins (Brazil) & 54 \\
\hline 23 & Kivu (DRC) & 46 & Ucayali (Peru) & 55 \\
\hline 24 & North-Western (Zambia) & 47 & Sumatera Utara (Indonesia) & 56 \\
\hline 25 & Shan (Myanmar) & 48 & Bandundu (DRC) & 57 \\
\hline 33 & Kasaï-Occidental (DRC) & 53 & Piauí (Brazil) & 63 \\
\hline 34 & Jambi (Indonesia) & 54 & Madre de Dios (Peru) & 63 \\
\hline 35 & Kasaï-Oriental (DRC) & 54 & North-Western (Zambia) & 64 \\
\hline 36 & Madre de Dios (Peru) & 55 & Kalimantan Utara (Indonesia) & 64 \\
\hline 37 & Amazonas (Venezuela) & 55 & Papua Barat (Indonesia) & 65 \\
\hline 38 & Cuvette (Rep. Congo) & 56 & Shan (Myanmar) & 66 \\
\hline 39 & Amapá (Brazil) & 56 & Kalimantan Selatan (Indonesia) & 66 \\
\hline 40 & Acre (Brazil) & 57 & Kasaï-Occidental (DRC) & 67 \\
\hline 41 & Goiás (Brazil) & 57 & Pahang (Malaysia) & 67 \\
\hline 42 & La Paz (Bolivia) & 58 & Aceh (Indonesia) & 68 \\
\hline 43 & Moxico (Angola) & 58 & Sumatera Barat (Indonesia) & 68 \\
\hline 44 & Delta Amacuro (Venezuela) & 59 & East Sepik (PNG) & 69 \\
\hline 45 & Est (Cameroon) & 59 & Kasaï-Oriental (DRC) & 69 \\
\hline 46 & Sipaliwini (Suriname) & 60 & Sabah (Malaysia) & 69 \\
\hline 47 & Amazonas (Colombia) & 60 & Kerala (India) & 70 \\
\hline 48 & Piauí (Brazil) & 61 & Sulawesi Tengah (Indonesia) & 70 \\
\hline 49 & Pando (Bolivia) & 61 & Gulf (PNG) & 71 \\
\hline 50 & Kalimantan Utara (Indonesia) & 62 & Likouala (Rep. Congo) & 71 \\
\hline
\end{tabular}

Italics, Only in top 50 jurisdictions in unweighted projected emissions, 2020-2050 (Busch et al., 2019). Bold, only in top 50 jurisdictions in projected emissions weighted by authority score. 


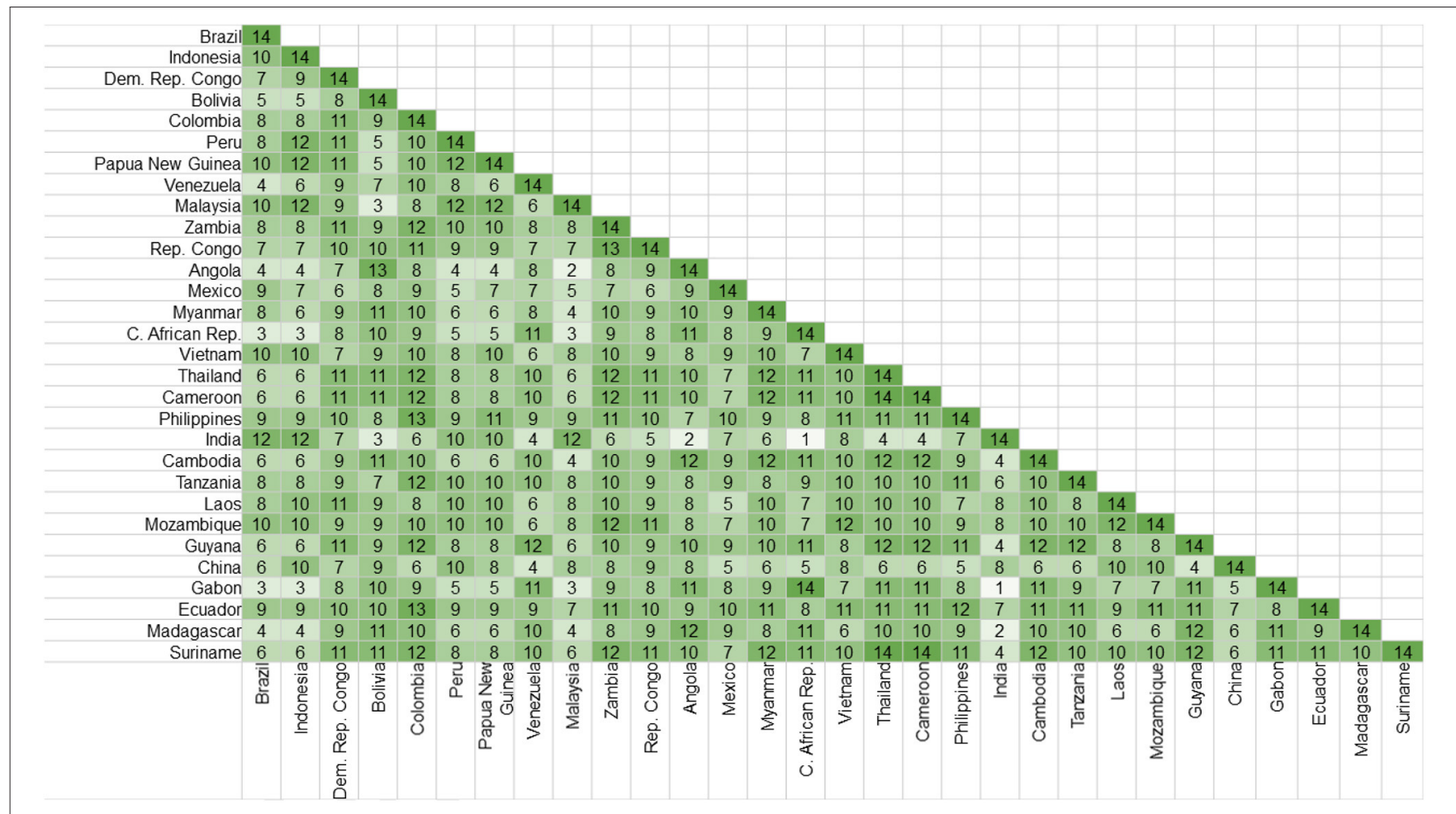

FIGURE 2 | Number of authorities (out of 14) with the same score in both countries, for each pair of countries.

are constrained in the type of taxes they are able to levy.

The type of general authority that second-tier governments have in the fewest countries, i.e., is in the bottom third, is police $(4 / 30)$. This suggests that law enforcement as a mechanism for reducing deforestation is more commonly the purview of the national government. In the middle third of general authority are courts (13/30) and elections (15/30).

The types of forest-related authority that second-tier governments have in the most countries, i.e., in the top third, include development planning (27/30) and road infrastructure $(21 / 30)$. This suggests that some of second-tier governments' greatest leverage for avoiding deforestation lies in the redirection of planned development away from forests, especially through road networks.

The types of forest-related authority that second-tier governments have in the fewest countries include land ownership $(3 / 30)$, permits for mining $(6 / 30)$, Indigenous affairs $(8 / 30)$, and protected areas (8/30). Thus, forest conservation strategies related to these authorities would be better directed to other levels of government, typically national.

In an intermediate number of countries, i.e., in the middle third, second-tier governments have authority for spatial planning (16/30), permits for agriculture (12/30), and permits for logging (11/30), suggesting that forest conservation strategies related to these authorities may be appropriate for some countries but not others.

On average, a pair of authorities had the same score in 17.6 out of 30 countries (Figure 4; standard deviation $=5.1$ ).
The greatest commonality between any pair of authorities was between budgets and taxation, with the same score in 26 out of 30 countries. The least commonality was between land ownership and development planning, with the same score in only 6 out of 30 countries.

\section{Illustrative Prioritization}

The set of second-tier governments that are the highest priority for reducing climate emissions shifts after their authority to reduce deforestation is considered (Figure 5). Forty second-tier governments are among the top 50 second-tier jurisdictions based on both unweighted projected emissions from deforestation, and projected emissions from deforestation weighted by government authority. These 40 second-tier jurisdictions include 14 states in Brazil, 9 provinces in Indonesia, 7 departments in Democratic Republic of Congo, 3 regions in Peru, 2 departments in Bolivia, 1 department in Republic of Congo, 1 province in Papua New Guinea, 1 state in Malaysia, 1 state in Myanmar, and 1 province in Zambia. Initiatives to reduce emissions from deforestation in these jurisdictions are important whether or not government authority is considered.

After weighting for the authority of second-tier governments to reduce deforestation, the list of the 50 second-tier jurisdictions in the tropics that are the highest priority for reducing emissions from deforestation shifts to include 3 fewer states in Venezuela, 2 fewer departments in Bolivia, 1 less province in Angola, 1 less region in Cameroon, 1 less department in 


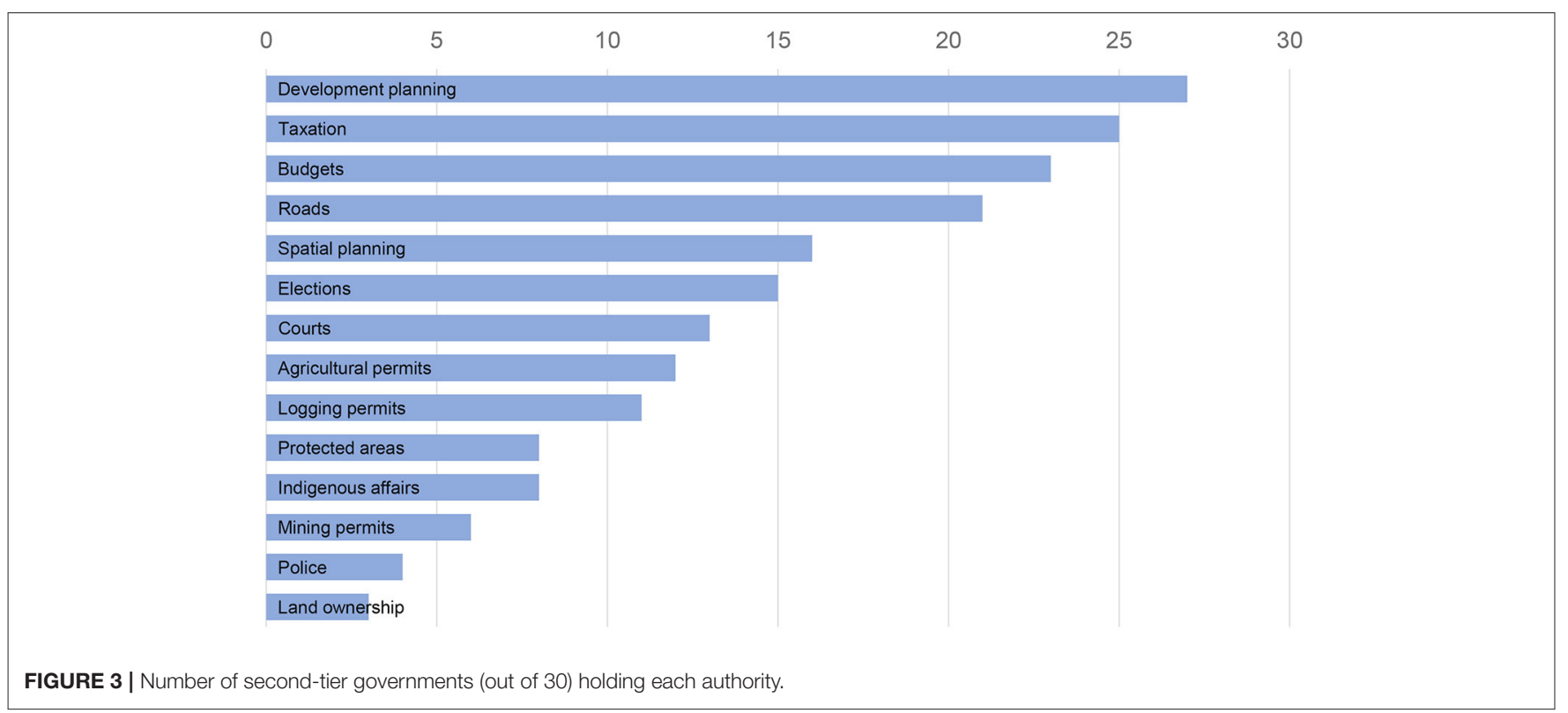

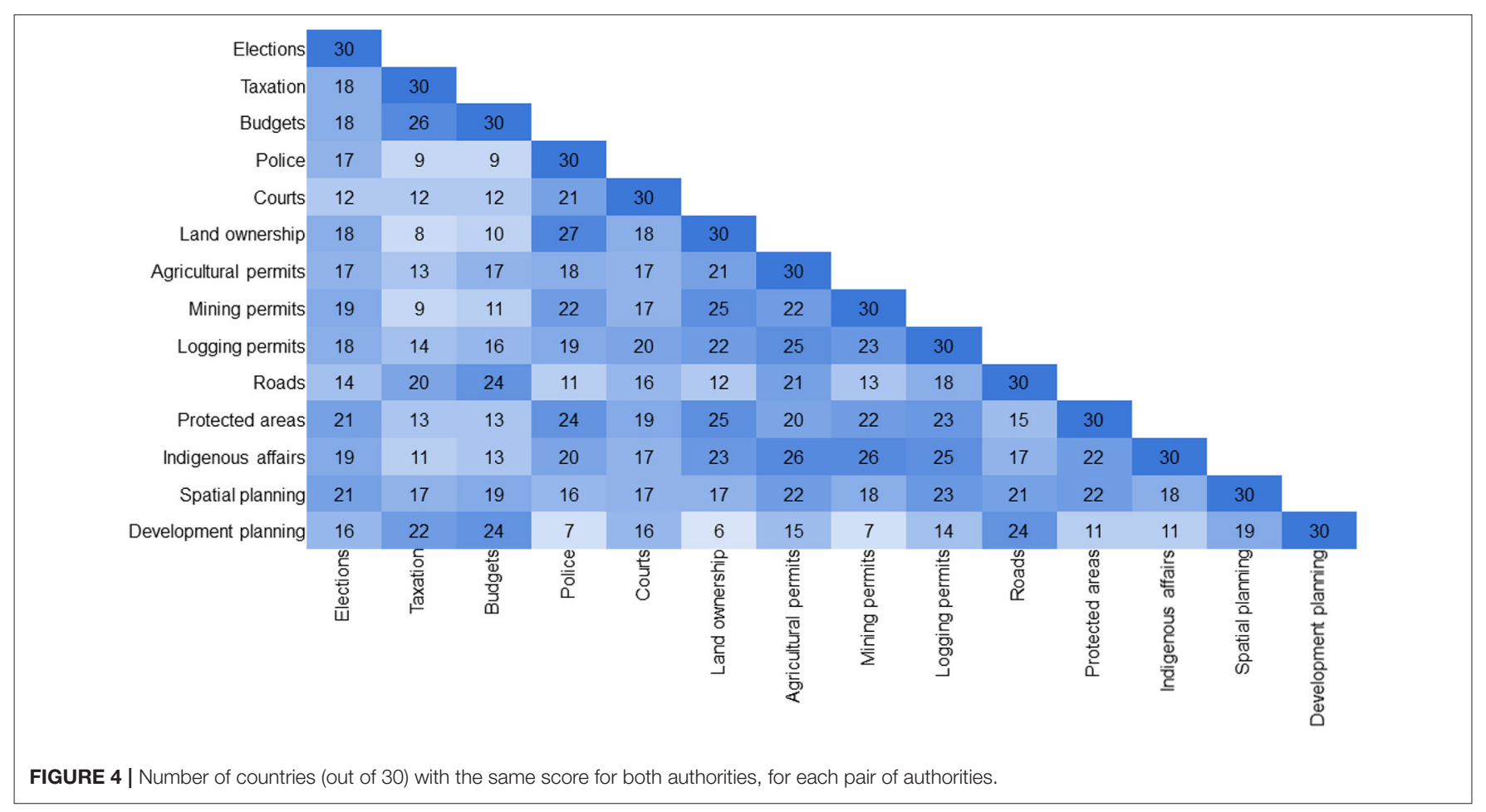

Colombia, 1 less department in Republic of Congo, and 1 less district in Suriname. Within these second-tier jurisdictions, initiatives to reduce emissions from deforestation are still among the most important, but should emphasize the role of national governments.

After weighting for the authority of second-tier governments, the list of the 50 second-tier jurisdictions in the tropics that are the highest priority for reducing emissions from deforestation shifts to include 5 more provinces in Indonesia, 2 more states in Malaysia, 2 more provinces in Papua New Guinea, and 1 more state in India. Initiatives to reduce emissions from deforestation in these jurisdictions represent potentially underappreciated opportunities.

There is substantial overlap between second-tier jurisdictions that we identified as high priority for reducing emissions from deforestation and second-tier jurisdictions that are participating in prominent international climate and forest initiatives. Of the 35 tropical second-tier jurisdictions in the Governors' Climate 


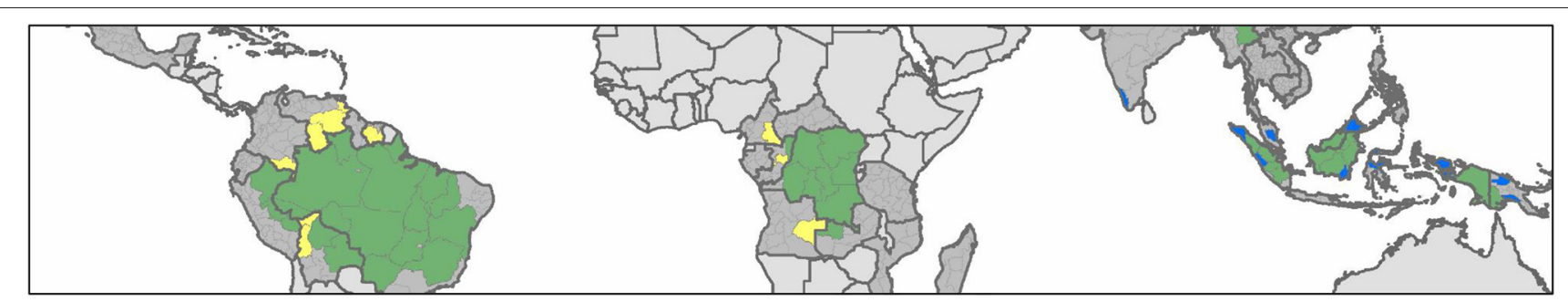

FIGURE 5 | The top 50 second-tier jurisdictions for projected emissions from deforestation shifts with and without consideration of authority score. Green=top 50 jurisdictions in both unweighted and weighted projected emissions. Yellow=top 50 jurisdictions in unweighted projected emissions, 2020-2050 (Busch et al., 2019) only. Blue=top 50 jurisdictions in projected emissions weighted by authority score only.

and Forest Task Force (GCF, 2019), 18 are among the top 50 unweighted, while 19 are among the top 50 weighted. Of the more than 200 second-tier jurisdictions worldwide in the Under2 Coalition (The Climate Group, 2019), 12 are in the top 50 unweighted, while 13 are in the top 50 weighted. Of the 21 second-tier jurisdictions that are signatories to the New York Declaration on Forests (United Nations, 2014), 8 are in the top 50 unweighted, while 9 are in the top 50 weighted.

\section{DISCUSSION}

Second-tier governments possess a range of authorities that can be used to reduce deforestation. But there is a great deal of variation across countries. The countries where secondtier governments possess the most authority for reducing deforestation, among the 30 we studied, are India, Brazil, Indonesia, Malaysia, Papua New Guinea, Peru, China, Laos, Mozambique, and Vietnam. International initiatives focused on supporting second-tier governments to reduce deforestation would do well to upweight support toward states and provinces in these countries, while also taking into account deeper countryspecific knowledge.

In contrast, second-tier governments possess the least authority in Central African Republic, Gabon, Angola, Madagascar, Bolivia, Cambodia, Cameroon, Guyana, Suriname, Thailand, and Venezuela. In these countries international support for reducing deforestation might be best directed toward the national governments. Consideration of the authority of second-tier governments shifts the list of jurisdictions that could be a priority away from jurisdictions in Africa (Angola, Cameroon, Republic of Congo) and Latin America (Bolivia, Colombia, Suriname, Venezuela) and toward jurisdictions in Asia (India, Indonesia, Malaysia, and Papua New Guinea).

Authorities also vary considerably in the degree to which they are possessed by second-tier governments. The authorities most often possessed by second-tier governments include development planning, taxation, budgeting, and road infrastructure. Initiatives for reducing deforestation would generally do well to focus support on second-tier governments' commitments and actions in these sectors.
In contrast, the authorities least often possessed by secondtier governments include authority for land ownership, police, permits for mining, Indigenous affairs, and protected areas. Initiatives for reducing deforestation would do well to focus support in these sectors on national governments.

Our data set on the relative authority possessed by secondtier governments in different countries, when complemented with deeper country-specific knowledge, can be used by forest conservation initiatives to prioritize support across countries and sectors.

\section{DATA AVAILABILITY STATEMENT}

All datasets generated for this study are included in the article/Supplementary Material.

\section{AUTHOR CONTRIBUTIONS}

JB designed the study and wrote the paper. OA collected the data and constructed the database.

\section{FUNDING}

Norwegian Agency for Development Cooperation QZA-0701 QZA-16-0162.

\section{ACKNOWLEDGMENTS}

We are grateful to the Norwegian Agency for Development Cooperation for funding. Helpful personal communications on authorities in selected countries were provided by Juan Ardila, Rohini Chaturvedi, Radhika Dave, Sébastien Desbureaux, Ambe Che Ernest, Renzo Giudice Granados, Nindita Hapsari, Michelle Kalamandeen, David McGrath, and Triyoga Widiastomo. We thank members of the editorial board and two reviewers for helpful comments.

\section{SUPPLEMENTARY MATERIAL}

The Supplementary Material for this article can be found online at: https://www.frontiersin.org/articles/10.3389/ffgc.2020. 00001/full\#supplementary-material 


\section{REFERENCES}

Angelsen, A., and Kaimowitz, D. (1999). Rethinking the causes of deforestation: lessons from economic models. World Bank Res. Obs. 14, 73-98. doi: $10.1093 /$ wbro/14.1.73

Angelsen, A., and Rudel, T. K. (2013). Designing and implementing effective REDD + policies: a forest transition approach. Rev. Environ. Econ. Policy 7, 91-113. doi: 10.1093/reep/res022

APCOF (2019). African Policing Civilian Oversight Forum. Available online at: https://apcof.org/country-data/ (accessed October 1, 2019).

Ardiansyah, F., Marthen, A. A., and Amalia, N. (2015). Forest and Land-Use Governance in a Decentralized Indonesia: A Legal and Policy Review. Occasional paper 132. Center for International Forestry Research, Bogor, Indonesia.

Barber, C. P., Cochrane, M. A., Souza, C. M., and Laurance, W. F. (2014). Roads, deforestation, and the mitigating effect of protected areas in the Amazon. Biol. Conservation 177, 203-209. doi: 10.1016/j.biocon.2014.07.004

Boyd, W., Stickler, C., Duchelle, A. E., Seymour, F., Nepstad, D., Bahar, N. H. A., et al. (2018). Jurisdictional Approaches to REDD+ and Low Emissions Development: Progress and Prospects. Working Paper. World Resources Institute, Washington, DC.

Burivalova, Z., Allnutt, T. F., Rademacher, D., Schlemm, A., Wilcove, D. S., and Butler, R. A. (2019). What works in tropical forest conservation, and what does not: effectiveness of four strategies in terms of environmental, social, and economic outcomes. Conserv. Sci. Pract. 1:e28. doi: 10.1111/csp2.28

Busch, J., and Ferretti-Gallon, K. (2017). What drives deforestation and what stops it? A meta-analysis. Rev. Environ. Econ. Policy 11, 3-23. doi: 10.1093/reep/rew013

Busch, J., Lubowski, R., Godoy, F., Steininger, M., Yusuf, A., Austin, K., et al. (2012). Structuring economic incentives to reduce emissions from deforestation within Indonesia. Proc. Natl. Acad. Sci. U.S.A. 109, 1062-1067. doi: $10.1073 /$ pnas.1109034109

Busch, J., and Mukherjee, A. (2017). Encouraging state governments to protect and restore forest using ecological fiscal transfers: India's Tax Revenue Distribution Reform. Conserv. Lett. 11:e12416. doi: 10.1111/conl.12416

Busch, J. B., Engelmann, J., Cook-Patton, S., Griscom, B., Kroeger, T., Possingham, H., et al. (2019). Low-cost opportunities for carbon dioxide removal through tropical reforestation. Nat. Clim. Change 9, 463-466. doi: 10.1038/s41558-019-0485-x

Butsic, V., Baumann, M., Shortland, A., Walker, S., and Kuemmerle, T. (2015). Conservation and conflict in the democratic Republic of Congo: the impacts of warfare, mining, and protected areas on deforestation. Biol. Conserv. 191, 266-273. doi: 10.1016/j.biocon.2015.06.037

Carrillo Fuentes, J. C., Velasco Ramirez, A. (2016). Estudio Legal: Facultades $y$ Responsabilidades Del Manejo Forestall y Del Suelo Ante REDD+ en Mexico. Occasional paper 150. Center for International Forestry Research, Bogor, Indonesia.

Cattaneo, A. (2011). Robust design of multiscale programs to reduce deforestation. Environ. Dev. Econ. 16, 455-478. doi: 10.1017/S1355770X11000040

Chan Robles Virtual Law Library (2019). The Local Government Code of the Philippines. Available online at: http://www.chanrobles.com/localgovfulltext. html\#.XfFI-ehKhPY (accessed October 1, 2019).

Chomitz, K. (2007). At Loggerheads? Agricultural Expansion, Poverty Reduction and Environment in the Tropical Forests. Washington, DC: World Bank.

CIA (2019). The World Factbook. Washington, DC: Central Intelligence Agency. Available online at: https://www.cia.gov/library/publications/resources/theworld-factbook/ (accessed October 1, 2019).

Constitute Project (2019). Available online at: https://www.constituteproject.org/ (accessed October 1, 2019).

Cropper, M., Puri, J., and Griffiths, C. (2001). Predicting the location of deforestation: the role of roads and protected areas in north Thailand. Land Econ. 77, 172-186. doi: 10.2307/3147088

Curtis, P. G., Slay, C. M., Harris, N. L., Tyukavina, A., and Hansen, M. C. (2018). Classifying drivers of global forest loss. Science 361, 1108-1111. doi: 10.1126/science.aau3445

DeFries, R., Herold, M., Verchot, L., Macedo, M. N., and Shimabukuro, Y. (2013). Export-oriented deforestation in Mato Grosso: harbinger or exception for other tropical forests? Philos. Transact. R. Soc. 368:20120173. doi: $10.1098 /$ rstb.2012.0173 di Gregorio, M., Fatorelli, L., Paavola, J., Locatelli, B., Pramova, E, Nurrochmat DR, et al. (2019). Multi-level governance and power in climate change policy networks. Glob. Environ. Change 54, 64-77. doi: 10.1016/j.gloenvcha.2018.10.003

Fernandini, P. W., and Sousa, R. F. (2015). The Distribution of Powers and Responsibilities Affecting Forests, Land Use, and REDD+ Across Levels and Sectors in Peru: A Legal Study. Occasional Paper \#129. Bogor: Center for International Forestry Research.

Forsyth, T. (2009). "Multilevel, multiactor governance in REDD+: participation, integration and coordination," in Realising REDD+: National Strategy and Policy Options, ed Angelsen (Bogor: Center for International Forestry Research), 113-122.

GCF (2019). GCF Task Forest Member States. Governors' Climate and Forest Task Force. Available online at: https://www.gcftf.org/member-states (accessed August 7, 2019).

Geist, H. J., and Lambin, E. F. (2002). Proximate causes and underlying driving forces of tropical deforestation. Bioscience 52, 143-150. doi: 10.1641/00063568(2002)052 [0143:PCAUDF]2.0.CO;2

Herrera, D., Pfaff, A., and Robalino, J. (2019). Impacts of protected areas vary with the level of government: comparing avoided deforestation across agencies in the Brazilian Amazon. Proc. Natl. Acad. Sci. U.S.A. 116, 14916-14925. doi: 10.1073/pnas.1802877116

Hudson, R. A., Hanratty, D. M., and Weil, T. E. (1991). Bolivia: A Country Study. Washington, DC: Federal Research Division, Library of Congress.

IPBES (2019). Global Assessment Report on Biodiversity and Ecosystem Services. Bonn: Intergovernmental Science-Policy Platform on Biodiversity and Ecosystem Services.

IPCC (2014). Fifth Assessment Report. Geneva: Intergovernmental Panel on Climate Change.

Irawan, S., Widiastomo, T., Tacconi, L., Watts, J. D., and Steni, B. (2019). Exploring the design of jurisdictional REDD+: the case of Central Kalimantan, Indonesia. For. Policy Econ. 108:2 doi: 10.1016/j.forpol.2018. 12.009

Korhonen-Kurki, K., Brockhaus, M., Duchelle, A. E., Atmadja, S., Pham, T. T., and Schofield, L. (2013). Multiple levels and multiple challenges for measurement, reporting and verification of REDD+. Int. J. Commons 7, 344-366 doi: 10.18352/ijc.372

Korhonen-Kurki, K., Sehring, J., Brockhaus, M., and Di Gregorio, M. (2014). Enabling factors for establishing REDD+ in a context of weak governance. Climate Policy 14, 167-186. doi: 10.1080/14693062.2014.852022

Larson, A. M., Sarmiento Barletti, J. P., Ravikumar, A., and Korhonen-Kurki, K. (2018). "Multi-level governance: Some coordination problems cannot be solved through coordination," in Transforming REDD+ Angelsen ed. (Bogor: Center for International Forestry Research), 275.

Li, Q., and Reuveny, R. (2006). Democracy and environmental degradation. Int. Stud. Quart. 50, 935-956. doi: 10.1111/j.1468-2478.2006.00432.x

Mamun, A., Martin, W., and Tokgoz, S. (2017). Reforming Agricultural Subsidies for Improved Environmental Outcomes. IFPRI Discussion Paper 01891. Washington, DC: International Food Policy Research Institute.

Mbwambo, L. (2015). The Distribution of Powers and Responsibilities Affecting Forests, Land Use, and REDD+ Across Levels and Sectors in Tanzania: A Legal Study. Occasional paper 147. Center for International Forestry Research, Bogor, Indonesia.

Müller, R., Pistorius, T., Rohde, S., Gerold, G., and Pacheco, P. (2013). Policy options to reduce deforestation based on a systematic analysis of drivers and agents in lowland Bolivia. Land Use Policy 30, 895-907. doi: 10.1016/j.landusepol.2012.06.019

Mumbunan, S. (2018). Dana Alokasi Umum (DAU) Untuk Kabupaten Kaya Hutan. Brief Paper, University of Indonesia, Jakarta, Indonesia.

Myers, R., Larson, A. M., Ravikumar, A., Kowler, L. F., Yang, A., and Trench, T. (2018). Messiness of forest governance: how technical approaches suppress politics in REDD+ and conservation projects. Glob. Environ. Change 50, 314-324. doi: 10.1016/j.gloenvcha.2018.02.015

Nepstad, D., Irawan, S., Bezerra,T., Boyd, W., Stickler, C., Shimada, J., et al. (2013a). More food, more forests, fewer emissions, better livelihoods: linking REDD+, sustainable supply chains and domestic policy in Brazil, Indonesia and Colombia. Carbon Manage. 6, 639-658. doi: 10.4155/cmt. 13.65 
Nepstad, D. C., Boyd, W., Stickler, C. M., Bezerra, T., and Azevedo, A. A. (2013b). Responding to climate change and the global land crisis: REDD+, market transformation and low-emissions rural development. Philos. Trans. R. Soc. Lond. B. Biol. Sci. 368:20120167. doi: 10.1098/rstb.2012.0167

OECD (2016). Mexico. Paris: Organization for Economic Cooperation and Development. Available online at: https://www.oecd.org/regional/regionalpolicy/profile-Mexico.pdf (accessed October 1, 2019).

Pedlowski, M. A., Dale, V. H., Matricardi, E. A. T., and da Silva Filho, E. P. (1997). Patterns and impacts of deforestation in Rondonia, Brazil. Landsc. Urban Plan. 38, 149-157. doi: 10.1016/S0169-2046(97)00030-3

Pfaff, A., Amacher, G. S., and Sills, E. O. (2013). Realistic REDD: improving the forest impacts of domestic policies in different settings. Rev. Environ. Econ. Policy 7, 114-135. doi: 10.1093/reep/res023

Phelps, J., Webb, E. L., and Agrawal, A. (2010). Does REDD+ threaten to recentralize forest governance? Science 328, 312-313. doi: $10.1126 /$ science. 1187774

Putz, F. E., and Romero, C. (2015). Futures of Tropical Production Forests. CIFOR Occasional Paper 143, Center for International Forestry Research, Bogor, Indonesia.

Ravikumar, A., Larson, A. M., Duchelle, A. E., Myers, R., and Gonzales Tovar, J. (2015). Multilevel governance challenges in transitioning towards a national approach for REDD+: evidence from 23 subnational REDD+ initiatives. Int. J. Commons 9, 909-931. doi: 10.18352/ijc.593

Rice, R., Gullison, E., and Reid, J. W. (1997). Can sustainable management save tropical forests? Sci. Am. 276, 44-49. doi: 10.1038/scientificamerican0497-44

Rudel, T. K., Defries, R., Asner, G. P., and Laurance, W. F. (2009). Changing drivers of deforestation and new opportunities for conservation. Conserv. Biol. 23, 1396-1405. doi: 10.1111/j.1523-1739.2009.01332.x

Seymour, F., and Busch, J. (2016). Why Forests? Why Now? The Science, Economics, and Politics of Tropical Forests and Climate Change. Washington, DC: Center for Global Development.

Stickler, C., Duchelle, A. E., Nepstad, D., and Ardila, J. P. (2018). "Subnational Jurisdictional Approaches: Policy Innovation and Partnerships for Change," in Transforming REDD+: Lessons and New Directions, eds A. Angelsen, C. Martius, V. De Sy, A. E. Duchelle, A. M. Larson, P. T. Thuy (Bogor: Center for International Forestry Research), 145-159.

Sundstrom, A. (2016). Understanding illegality and corruption in forest governance. J. Environ. Manage. 181, 779-790. doi: 10.1016/j.jenvman.2016.07.020

The Climate Group (2019). Under 2: Our Members. Available online at: https:// www.under2coalition.org/members (accessed August 7, 2019).
Trung, L. Q., Phuong, V. T., Yang, A., and Hai, V. D. (2015). The Distribution of Powers and Responsibilities Affecting Forests, Land Use, and REDD+ Across Levels and Sectors in Vietnam: A Legal Study. Occasional paper 137. Center for International Forestry Research, Bogor, Indonesia.

UNEP-WCMC (2014). World Database on Protected Areas. United Nations Environment Programme-World Conservation Monitoring Centre. Oxford, UK. Available online at: https://www.unep-wcmc.org/resources-and-data/ wdpa (accessed October 1, 2019).

UNFCCC (2013). Warsaw Framework for REDD-Plus. United Nations Framework Convention on Climate Change. Available online at: https://unfccc.int/topics/ land-use/resources/warsaw-framework-for-redd-plus (accessed October 1, 2019).

United Nations (2014). New York Declaration on Forests. Available online at: https://nydfglobalplatform.org/wp-content/uploads/2017/10/NYDF_ Declaration.pdf (accessed October 1, 2019).

USAID (2019). LandLinks Country Profiles. United States Agency for International Development. Available online at: https://www.land-links.org/countryprofiles/ (accessed October 1, 2019).

Vasconcelos, V., Hadad, R. M., and Martins, P. P. (2013). Methodologies for integrated studies of natural resources: a discussion on ecological-economic Zoning. Pesquisas em Geociencias 40, 21-30. doi: 10.22456/1807-9806. 40829

Wieland, F., and Farfan, S. (2015). The Distribution of Powers and Responsibilities Affecting Forests, Land Use, and REDD+ Across Levels and Sectors in Peru. Occasional paper 129. Center for International Forestry Research, Bogor, Indonesia.

WRI (2019). Forest Legality Initiative. Washington, DC: World Resources Institute. Wunder, S. (2005). Payments for Environmental Services: Some Nuts and Bolts. CIFOR Occasional Paper 42, Center for International Forestry Research, Bogor, Indonesia

Conflict of Interest: The authors declare that the research was conducted in the absence of any commercial or financial relationships that could be construed as a potential conflict of interest.

Copyright $(2020$ Busch and Amarjargal. This is an open-access article distributed under the terms of the Creative Commons Attribution License (CC BY). The use, distribution or reproduction in other forums is permitted, provided the original author(s) and the copyright owner(s) are credited and that the original publication in this journal is cited, in accordance with accepted academic practice. No use, distribution or reproduction is permitted which does not comply with these terms. 